\title{
Six Illuminated Videos
}

SPECIAL COLLECTION:

SPECIAL ISSUE OF

ILLUMINATED VIDEOS

VIDEO ARTICLE

ANGELA VIORA (1)

AL EVANGELISTA (1)

SONIA YORK-PRYCE (1)

CLAIRE VIONNET (1)

ANDRÉ DRAMÉ

W. DONNIE SCALLY (D)

ALEN AGARONOV (1)

*Author affiliations can be found in the back matter of this article

\section{ब나}

Open Library of Humanities

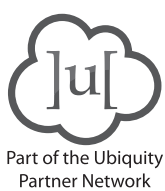

Part of the Ubiquity
CORRESPONDING AUTHOR:

\section{Ben Spatz}

University of Huddersfield, UK b.spatz@hud.ac.uk

KEYWORDS:

Filipinx; Filipina; Filipino; Filipinx/a/o-American; diaspora; queer; dance; queer dance; auto-ethnography; Philippines; Anti-colonialism; Sound; Materialism; Sensory Reconfiguration; Martial Arts; Combat Sports

TO CITE THIS ARTICLE: Viora, A, Evangelista, A, York-Pryce, S, Vionnet, C, Dramé, A, Scally, WD and Agaronov, A. 2021. Six Illuminated Videos. Journal of Embodied Research, 4(2): 2 (31:25). DOI: https://doi. org/10.16995/jer.91 
VIDEO ARTICLE

Available to view here: https://doi.org/10.16995/jer.91.

Available for download here: https://doi.org/10.16995/jer.91.s1.

\section{VIDEO ARTICLE TRANSCRIPT}

[Note: This is a transcript of a video article. Individual elements from the transcript, such as metadata and reference lists, may appear more than once in the document, in order to be properly read and accessed by automated systems. The transcript can be used as a placeholder or reference when it is not possible to embed the actual video, which can be found by following the DOI.]

[00:10]

JER 4(2): 2 - “Six Illuminated Videos" (31:25)

Angela Viora (2:25)

"Phenomenology of big hair caught up in the wind at night"

Al Evangelista (4:42)

"How to dance with Filipinx ancestors?"

Sonia York-Pryce (4:48)

"Sôma"

Claire Vionnet and André Dramé (5:39)

"Dereskina"

W. Donnie Scally (6:00)

"Reconfiguring sensory experience: The sounds of 100 rounds of karate shadowboxing"

Alen Agaronov (7:00)

"Meeting the definition of human subjects research: A case study"

[00:20]

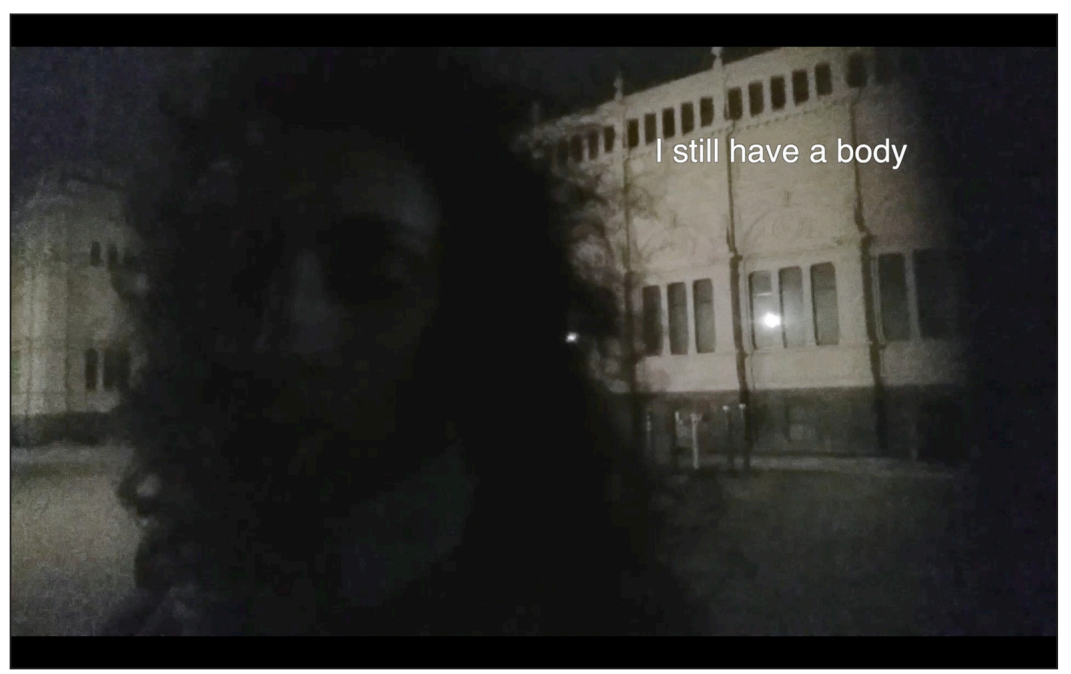

\section{PHENOMENOLOGY OF BIG HAIR CAUGHT UP IN THE WIND AT NIGHT}

\section{Angela Viora}

Melbourne, October 2020.

Stage-4 lockdown.

Permission to go out for 1 hour within $5 \mathrm{~km}$.

Curfew between 9pm-5am.

8-9pm: the city is deserted

fresh air hits my body

I still have a body 
the wind reminds me to breathe

I am my nostrils, my throat and my lungs

there is a tactile life outside the online world

which I need to remember of

a body outside "my head" and my laptop

atmospheres temperatures sounds climatic agents

colours trees textures surfaces volumes

I AM ALIVE

SONO VIVA

I stand tall and still for more air

my hair moves, I am alive

I breathe deeply, I am alive

the wind blows on me

reappropriation

corporeality

my fleshy body

resists alienation

I am an alive

moving

touchable

vulnerable

smelly

pulsating

body

\section{BREATHE}

(c) Angela Viora 2021

editing Sabrina Talarico

[02:50]

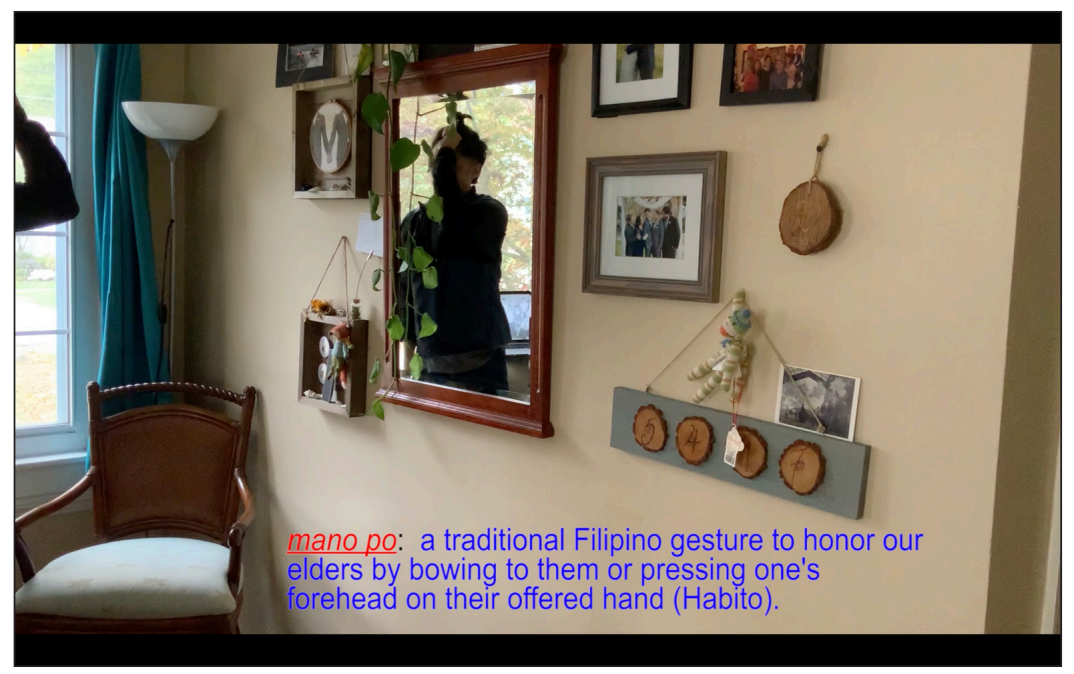

How to Dance with Filipinx Ancestors?

\section{a video essay by}

Al Evangelista 
This video essay approaches three main questions: What non-linear ways of thinking about history can be embodied? How does historical documentation and analysis alongside a moving body offer multiple ways of knowing? How to dance with pamilya, Pilipina/o/x, and Pilipina/o/xAmerican history? This unedited video was originally a rehearsal for Patawali, a Filipinx-American History Month film festival. How to Dance with Filipinx Ancestors? offers a step-by-step guide to move through diasporic themes illustrated by "illuminated" text.

Step 1

play Gimme Chills, No-No Boy

Step 2

mano po all the ancestors in the space today

mano po: a traditional Filipino gesture to honor our elders by bowing to them or pressing one's forehead on their offered hand (Habito).

Step $3 a$

Humbly adapt Yen Le Espiritu's Critical Refuge(e) Studies

Step $3 b$

"[I]nvisible things are not necessarily not there. How do we write about absences? How do we compel others to look for the things that are seemingly not there? How do we imagine beyond the limits of what is already stated to be understandable?" (Espiritu 20).

Step 3c

[I]nvisible things are not necessarily not there. How do we [dance] about absences? How do we compel others to move for the things that are seemingly not there? How do we [choreograph] beyond the limits of what is already stated to be understandable? (Espiritu 20) [my edits]

Step 4

Remind yourself that you were introduced to Espiritu's work by Julian Saporiti, the person singing the song you are currently dancing to.

“'Gimme Chills' is a song about the long, complicated history of the Philippines. [... T] This song, through its mess of proper nouns, juxtaposes and explores the contradictions of conquest, movement, and imperialism which has shaped so much of Southeast Asia" Julian Saporiti/No-No Boy

Step 5

After reaching for ancestors, strength, care, hope, and many unnameable things, bring all of that in towards you.

"But the Philippines and its diaspora can never forget the legacy of U.S. imperialism, as its effects on the Philippines's territory, laws, economy, citizenry, and diaspora are still unfolding [...]" (Abigail De Kosnik in Perfect Covers: Filipino Musical Mimicry and Transmedia Performance 157).

\section{Last Step}

Remind yourself there are multiple ways to dance with your Filipinx ancestors. See Ani Gavino, Jay Carlon, Lucy San Mae Pablo Burns, J. Lorenzo Perillo, and Martin Manalansan.

How to Dance with Filipinx Ancestors?

Gimme Chills written by Julian Saporiti. 1975, No-No Boy, Smithsonian Folkways 2021.

Espiritu, Yen Le. (2014). Critical Refuge(e) Studies. Body Counts: The Vietnam War and Militarized Refugees. (pp. 1-23). University of California Press.

Habito, Cielito F. (2021). 'Mano po' and other treasures. https://opinion.inquirer.net/109755/manopo-treasures

Kosnik, Abigail D. (2017). Perfect Covers: Filipino Musical Mimicry and Transmedia Performance. Verge: Studies in Global Asias, 3(1). 
Keywords: Filipinx, Filipina, Filipino, Filipinx/a/o-American, diaspora, queer, dance, queer dance, auto-ethnography, Philippines, Anti-colonialism

The author declares that he has no competing interests.

How to Dance with Filipinx Ancestors

a video essay by Al Evangelista

[Lyrics to "Gimme Chills":]

Give me rhyme for no reason

Give me the world for a start

Give me all the treason you might carry in your heart

Give me life fantastic

Get me over the hill

Until the day I go, gimme chills

Gimme seas of blue waves

Tangled round my hands

Give me sand and soft shoes

Evenings with the band

Sing me songs so classic, like cherry cola thrills

Lips on glass not plastic

I know you will

Give me trial without jury

Give me Imelda Marcos' shoes

Give me another century to make it up to you

Hear of the Sangley rebellion?

Twenty thousand killed

16 and 03 , gimme chills

Give me Dewey in Manila

Give me the Pearl of the Orient

Give me the USS Olympia, nine ships heaven sent

Skype me Christmas eve from Doha

Toast me New Year's from Crown Hill

And if we never get back home, gimme chills

Give me Lopez de Legazpi

From Jalisco to Cebu

Make me your religion

I'll watch over you

Dream of Spanish autumns

From New Granada to old Castile

Over all them miles, gimme chills

Give me rhyme for no reason

Give me your balikbayan box,

Give me coca-cola, Chuck Taylors, and an Apple watch

Give me your Asian manhood

Give me Duterte's sober will

Black flags in Marawi, gimme chills 


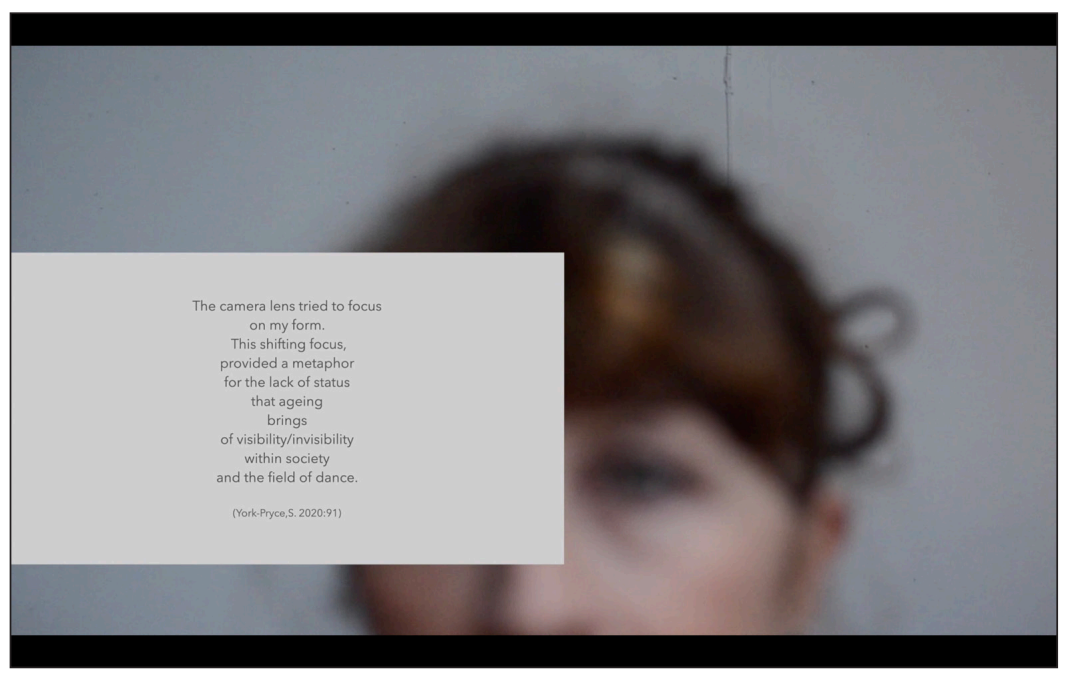

\section{SÔMA}

\section{an illuminated video essay}

sôma

Archive footage produced in 2017 as

Experimental research to film

Myself

Unaided.

This solo work was designed as an

investigation

To highlight

\section{CORPOREAL DIFFERENCE}

using my body as object

and ageing as the subject

The camera lens tried to focus

on my form.

This shifting focus,

provided a metaphor

for the lack of status

that ageing

brings

of visibility/invisibility

within society

and the field of dance.

(York-Pryce, S. 2020: 91)

"can I have become

a different being

while I still remain myself?"

(De Beauvoir, 1977: 315)

Framing the ageing body.

How is the older female body viewed?

Can boundaries be widened or removed altogether within classical ballet and contemporary dance to give a place and value to the older dancer?

"Almost no-one questions how old people feel only seeing younger people on stage. What would happen

if we altered that perspective?"

(Lilja. 2006: 22). 
"There is a lack of older dancers - we don't see older dancers"

Hege Haargenrud (2015)

"What is seen

and

what is thought.

What is thought

and

what is seen."

(Rancière, J. 2009: 75)

"The ageing body challenges

The system

Of dance and the

Politics

Of

Aesthetics

In

dance."

(Nakajima, N. 2017: 25)

It is writing from the void, and it amounts to a

writing from our own

bodies,

from the moment to

moment of our own

existence.

(Kozel, S. 2007: 9)

embodiment

There are uncertain expectations of what we imagine when watching an older dancer because it is not common; culturally we veer away from decline. By being aged, in this case over 40, they are different, a corporeal difference.

(York-Pryce 2020:134).

is it appropriate?

is it inappropriate?

"My body is my dwelling place.

I move within a context.

My movement expresses the

place I am in, and it is

through the body that

I turn it into

experience."

(Lilja, E. 2006: 16)

"The dance body is the

emotional body.

The physical body,

the instrument

through which

it is expressed."

(Tully, R. 2008: 9) 
must I have a

dance-by-date?

My aim is to change perceptions

by bringing

a new understanding described

by Gullette for "age-on-the-body."

To draw attention to the

discrimination

that dancers suffer and to enlighten

others unaware

of the impact of ageism in the

dance world.

(Gullette, M. M. 2003: 9)

I AM

MARKED

BY CORPOREAL DIFFERENCE

\section{CREDITS}

Filmed and performed by Sonia York-Pryce

Music composed by Ölafur Arnalds and reproduced with his kind permission.

Loftið Verður Skyndilega Kalt (The Air Suddenly Goes Cold).

Written and performed by Ólafur Arnalds

Published by Kobalt Music Publishing

Courtesy Of Erased Tapes Records

erasedtapes.com

Filmed on location at Hospitalfield House, Arbroath, Scotland. UK. (2017)

Sonia York-Pryce 2021.

https://soniayork-pryce.wixsite.com/mysite

\section{REFERENCES}

De Beauvoir, Simone. Old Age. Translated by Patrick O'Brian. Harmondsworth: Penguin Books, 1977.

Gullette, Margaret M. "Acting Age on Stage: Age Appropriate Casting, the Default Body and Valuing a Property of Having an Age.” Journal of Dramatic Theory and Criticism 18, no 1 (2003): 7-28.

Haargenrud, Hege. Use my Body While It Is Still Young, Hege Haargenrud (NO) Coda Dance Festival, Norway, VIMEO, https://vimeo.com/299748949 2015.

Kozel, Susan. Closer: Performance. Technologies. Phenomenology. Cambridge, MA: MIT Press, 2007.

Lilja, Efva. Movement as the Memory of the Body: New Choreographic Work for the Stage. Translated by Frank Perry. Stockholm: University of Dance, Committee for Artistic Research and Development. 2006.

Morris, Gay. "Bourdieu, the Body, and Graham's Post War Dance." Dance Research: The Journal of the Society for Dance Research 19, no. 2, Winter (2001):52-82. http://www.jstor.org/stable/1290976.

Nakajima, Nanako. "Overview” In The Aging Body in Dance: A Cross Cultural Perspective, edited by Nanako Nakajima and Gabriele Brandstetter, 11-27. London and New York: Routledge, 2017.

Rancière, Jacques. The Emancipated Spectator. Translated by Gregory Elliot. London, New York: Verso, 2009.

Tully, Roger. On the Teaching of Classical Ballet, A Manual. Rome: New Books. 2008.

York-Pryce, Sonia. "A body of work." Journal of Dance, Movement \& Spiritualities 6, no 1 \& 2 (2020): 133-153.

York-Pryce, Sonia. "Ageism and the Mature Dancer". Thesis. Griffith University. https://doi. org/10.25904/1912/3928 


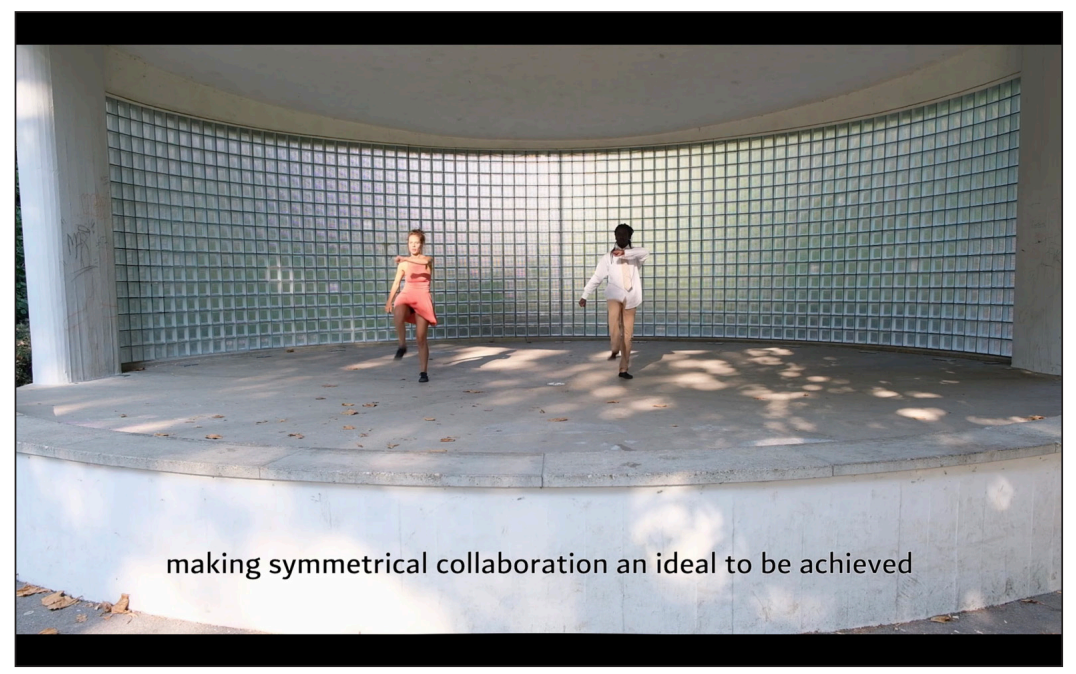

\section{Dereskina}

A dance production between Claire Vionnet, anthropologist \& dancer from Bern and André Dramé, former dancer of Cie Jant-Bi in Dakar

The piece was created in 2020 during partial lockdowns in Switzerland, becoming a journey into the unfamiliar and the unknown of creation

The two dancers met during Claire's investigation into the question of intimacy in Contemporary Dance

Fieldwork was interrupted by Covid-19

and found another actualization through this collaboration

Dereskina is an attempt to create a harmonious gesture between here and there

between the close and the far

How to avoid epistemic violence of otherness' representation?

In the research-creation, we explore our respective conceptions of movement, body and performance

through investigating the question of appropriation of gestures

We mixed Sabar - André's Senegalese tradition -

with Djembe and Contemporary Dance

Dereskina is an invented term composed of "der"

(skin in wolof) and skin

We felt that dancing the gesture of otherness

allows us to enter under the skin

Copying another's gesture transformed our anchoring, as well

as body axis and posture

By doing this, we experienced another sense of moving

and another way of being in the world

How to perform African dances beyond exotic representation?

Can bodies work through their blackness/whiteness?

What are the colonial residues still present in encounters between the North and the South?

Co-creation offers the possibility to enter in another

gestural, emotional and artistic language

It's more than the mimesis of a gestural shape

By co-creating, we invented together the sense of movement -

sensorial and semantic 
We produced together the meaning of our dance

Moving, breathing and sweating together

created an intimate bodily experience

The appropriation of another's body language invites us to feel beyond the skin

to feel with and through the other

Harmony finally came out of friction

besides misunderstanding and opposite opinion

about contemporary dance, dramaturgy and performance

The bigger confrontation was the written facing oral mode of communication

Since André doesn't share the written culture, academic writing is de facto exclusive

making symmetrical collaboration an ideal to be achieved

How can ethnographic accounts also address our counterparts?

We constantly had to learn to inhabit the world from another posture, changing our expectations

This only became possible through long conversations

and attempt to understand the other from their "skin"

perspective

beyond racial discrimination

Dance is an intercultural laboratory generating intimacy but also resistance and confrontation

Dereskina was an attempt of harmonious gesture based on difference

going beyond the asymmetrical relationship between a scientific subject and an artistic object

bypassing the reductionist exhibition of blackness in a traditional past

Most important was to show the contemporaneity of 'African dance' as a practice in ongoing transformation

and to claim for the symmetry between western and non-western cultural practices

André settled in 2016 in Switzerland after ten years intensive training and touring

Over the years, he improved his anthropologist's gaze on western behaviors and attitudes

we always laughed as he was ironically playing out Swiss modes of communication

Claire also had to learn Swiss culture, but as a child

When her family moved back to Switzerland after an early childhood in Cameroon

Recording: Alain Vuilleumier

Music :

TMPLT - Tho Ara Square

Gidge - Fauna Pt II

Djembe 


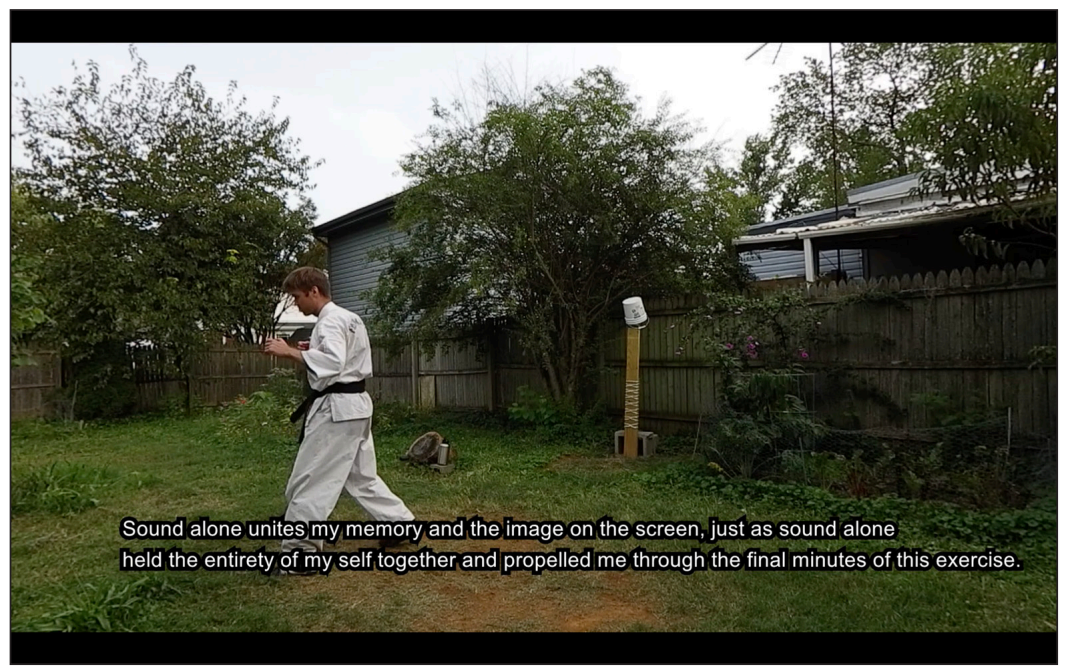

\section{Reconfiguring Sensory Experience: The Sounds of 100 Rounds of Karate Shadowboxing}

\section{W. Donnie Scally}

Abstract

Training, competition, and performance in martial arts provide a stage where practitioners' minds and bodies are continually revised, laying bare the techniques, processes, negotiations, and experiences involved in making and remaking the fighter's self. Through years of training and competition in Enshin Karate, a bareknuckle, knockdown-rules karate style, the author's body-including muscle, bone, skin, coordination, and perception-has changed to fit the art and the sport. Sensory shifts are among the most striking of these changes. In the most chaotic and high-pressure moments of training and competition, an experienced fighter may seem to feel sound or hear pain, shifting distracting, demoralizing, or damaging sensory phenomena to another mode better equipped to maintain performance in the moment. Sound has come to take on an important haptic and anesthetic role in the author's martial arts practice.

This article shares video taken of the final two of 100 shadowboxing rounds completed in a single session and discusses how this video relates to the author's direct sensory experience. Years of hard training and high-pressure competition can alter even the perceptive schema and sensory hierarchies that otherwise appear fundamental to our experience, and this video article represents an early step in the exploration of the limits of that directed self-modification. The author describes how, over the course of 100 rounds, sound begins to dominate his sensory experience. This article also demonstrates the potential for sound to cut across forms and media of memory, anchoring and uniting seemingly disjunct representations into an intelligible, if still contradictory, whole. The cultivated reconfiguration of the senses through experience with sites of extreme sensation has profound implications for the understanding of sound's role in embodiment, complicating and potentially extending everyday understandings of the body's limits and the limits of self-modification. Analysis of the disjunctures and connections between organically housed personal memory, associated with direct sensory experience, and digitally housed media representing the same phenomenon illuminates the role of particular phenomena-in this case sound-that may otherwise be understood as secondary to the visual in connecting these seemingly divergent mnemonics.

Keywords: Sound, Materialism, Sensory Reconfiguration, Martial Arts, Combat Sports

This video article is a contribution to an ongoing, multi-work individual and collaboration investigation of sound as a material technology of embodiment in combat sports, currently being conducted by the author and James Raymond Ace (UCLA). While the author bears full responsibility for the ideas presented, the article should be understood in the context of this ongoing conversation and in the broader context of materialist investigation of embodiment and the senses.

\section{Introduction}

In the fall of 2019, I began training for a 100-round fight, a harsh test of endurance and spirit in knockdown-rules karate styles. In this challenge, a single fighter completes 100 full-contact 
rounds with minimal rest, each against a fresh opponent. The length and specific rules vary. I am using two-minute rounds, with ten-second breaks between each. The video in this article displays the final two rounds of my first attempt at 100 rounds of shadowboxing. Encouraged by this exploratory foray, as of this article's publication, I continue to train toward my eventual goal of 100-round fight. During the COVID-19 pandemic, my training has been exclusively solo, and I expect my way of sensing the world will shift further, particularly as a reintroduce hard contact in my training. Training and competition has already altered my body, including my senses. Sound in particular now serves situationally important haptic and anesthetic functions. Through a shifting of my perceptive framework to privilege the aural, I can maintain presence and appropriate tactical movement even in moments of profound physical disorientation. In competitions and training, my attention to sound regulates my breathing and defers the pain of exhaustion and repeated impact.

This project is informed by existing work by scholars such as Paul Bowman (2018) in the budding field of martial arts studies and work on martial arts and embodiment (Spencer 2012; Jaquet and Deluz 2018). Previous studies have demonstrated that martial arts can train the senses within culturally specific frameworks, altering practitioners' perception of both the space around them (Mroz 202, 9-22) and their internal sensations (de Grace 2011, 123-143). Sound has not typically been a primary focus, though it is sometimes mentioned as part of complex sensory experience. My analysis draws on new materialist ideas questioning the nature of the human, its importance, and its stakes (Barad 2007; Haraway 1991; Haraway 2016; Jackson 2020) and discussions of the materiality of sonic phenomena and their co-constituency with personhood (Daughtry 2015; Eidsheim 2015; Redmond 2020). My approach is shaped by studies of the habitus of martial arts and combat sports and associated bodily technologies (Downey 2007, 201-226; Downey 2014, 113-117; Wacquant 2004; Wacquant 2011, 81-92) as well as sensory ethnography examining the cultural transmission of embodied knowledge in the arts, as exemplified by the work of Tomie Hahn (2007). Taking up Tomie Hahn's (2006, 87-96) call for investigation of sites of the sensually extreme, I seek the limits of the sensory shifts I have begun to experience through years of training.

How will I change by training for an undergoing the most punishing trial of my art? At the point of total exhaustion, where the boundaries of my own body no longer seem clear, what remains?

In these final rounds, sound alone holds my sensory world together, and its anesthetic functions seem to have reached their limit for me.

The sounds I make continue to suppress the nausea that came with exhaustion, but they no longer completely cover the feeling of my sore feet or the growing ache in my back.

I am incapable of lifting my limbs high enough or moving them fast enough to throw a punch or a kick with any speed or force without an accompanying vocalization.

Sound alone ties the images recorded in this video and my own sensory experience together. In the video, I watch a clearly dehydrated, exhausted, and dazed man with a face like mine attempt to throw punches and kicks as he shuffles in a slow circle.

My memory is of the dissolution of the body portrayed on the screen into a diffuse, vibrating field, only briefly collapsing into a denser form by strained vocalizations to execute one-to-twosecond combinations.

Sound alone unites my memory and the image on the screen, just as sound alone held the entirety of my self together and propelled me through the final minutes of this exercise.

I began strong, pushing myself harder and faster than usual, spurred on by my excitement at coming close to an early, but major milestone in my training.

After around 30 rounds, I had to start making sounds to suppress nausea. I grunted, shouted, and growled along with my techniques to keep it manageable.

Around round 60, the dizziness and nausea subsided. I began feeling light and mobile again.

I started to feel a high frequency vibration along my entire posterior-chain, strongest closer to the ground.

I had experienced this in previous, shorter training sessions building up to this one. 
My body vibrates, and if I stop moving for too long, it will feel like shaking from exhaustion, but as long as I use it, it feels more like energy building up and demanding release through movement and further exertion.

The vibration builds as a cumulative pressure that has to be vented.

Over time, the vibrating began to feel higher amplitude, but lower frequency. It eventually became uncomfortable, not painful, but with a similar level of discomfort to pain.

My lower back began to ache somewhere around round 70. By the upper 70s, the vibrating feeling no longer helped me move, it only provided greater discomfort.

Moving no longer made it completely subside and my limbs felt too heavy to throw them with the force, speed, or frequency that I previously had.

The pressure from the vibrating sensation began to build, no longer fully expressible at my maximum rate of exertion.

Around round 80 , my mind began to retreat.

I began to lose awareness of my body, experiencing only the now aggressive feeling of oscillation in my posterior chain, the pain in my lower back, and the environmental sounds: traffic, crickets, birds, the occasional subway train, plane, or helicopter, motorized lawn equipment, and the periodic angry chattering of squirrels.

The mechanical sounds somehow seemed to merge with the uncomfortable vibrating sensation, temporarily amplifying it and drowning out all thought except a vague, unfocused anger at being subjected to such intrusions.

The sounds from organic things did not affect me adversely, but they did not lessen my pain, discomfort, and exhaustion, nor did they focus me or bring my mind back. I began to shout more frequently.

I began to make some sound continuously, breathing loudly and growling under my breath just to keep producing sound. As I entered the final ten rounds, I remember ceasing to exist locally except when producing a sound.

I dissipated into a diffuse vibration, with a core of hot pain that only gradually bled into its surrounding oscillating field, merging into the environmental sounds, with no distinct boundary.

When I made a sound, this sonic field collapsed and my sense of a local self reemerged. In these moments, I remained uncomfortable, in pain, vibrating, and tired, but became capable of moving, thinking, and acting according to my training.

Watching this video, I recognize the image in the video as me. I recognize that I did these things, but I have no memory of an experience corresponding to the visual aspect.

The point of commonality is the sound. I remember these sounds - both the ones I make and the ones from my environment - and their recorded depiction is close enough to provide an anchor.

The sound reconciles my experience as I remember it with the image of the denser parts of myself on the screen as I watch.

I recognize the memories in my own mind and the memory embedded in the video as equally true. I did these things, yet the video and the experience seem unrelated. They have only sound in common.

At the point where my body no longer has the resources for sustained intention, or even to properly execute techniques carved and beaten into my muscle, bone and brain through countless repetitions, only sound remains.

Only my sound body, my self expressed, guided, and experienced as and through sound, remains intact and continuous, maintaining my sense of self in the moment of execution and linking my memories to the images captured in this video.

Competing Interest Statement:

The author declares that he has no competing interests.

References

Barad, Karen. 2007. Meeting the Universe Halfway: Quantum Physics and the Entanglement of Matter and Meaning. Durham, NC: Duke University Press. 
Bowman, Paul, ed. 2018. The Martial Arts Studies Reader. London: Rowman and Littlefield International.

Daughtry, Martin J. 2015. Listening to War: Sound, Music, Trauma and Survival in Wartime Iraq. New York: Oxford University Press.

de Grave, Jean-Marc. 2011. "The Training of Perception in Javanese Martial Arts." In Martial Arts as Embodied Knowledge: Asian Traditions in a Transnational World. Edited by D. S. Farrer and John Whalen-Bridge. Albany: State University of New York Press. 123-143.

Downey, Greg. 2014. “'Habitus in Extremis': From Embodied Culture to Bio-Cultural Development.” Body and Society 20(2): 201-226. DOI: https://doi.org/10.1177/1357034X14524603.

. 2007. "Producing Pain: Techniques and Technologies in No-Holds-Barred Fighting." Social Studies of Science 37(2): 201-226. DOI: https://doi.org/10.1177/0306312706072174.

Eidsheim, Nina Sun. 2015. Sensing Sound: Singing and Listening as Vibrational Practice. Durham, NC: Duke University Press.

Hahn, Tomie. 2007. Sensational Knowledge: Embodying Culture through Japanese Dance. Middletown, CT: Wesleyan University Press.

2006. “It's the RUTH': Sites of the Sensually Extreme.” The Drama Review 50(2): 87-96.

Haraway, Donna. 2016. Staying with the Trouble: Making Kin in the Chthulucene. Durham, NC: Duke University Press.

1991. Simians, Cyborgs, and Women: The Reinvention of Nature. New York: Routledge.

Jackson, Zakiyyah Iman. 2020. Becoming Human: Matter and Meaning in an Antiblack World. New York: New York University Press.

Jaquet, D. \& Deluz, V. 2018. "Moving in Late Medieval Harness: Exploration of a Lost Embodied Knowledge.” Journal of Embodied Research, 1(1), 2 (20:49). DOI: https://doi.org/10.16995/jer.7

Mroz, Daniel. 2020. “Taolu - The Master of Space.” Martial Arts Studies 10: 9-22. DOI: https://doi. org/10.18573/mas.111

Redmond, Shana. 2020. Everything Man: The Form and Function of Paul Robeson. Durham, NC: Duke University Press. eBook. DOI: https://doi.org/10.1353/book.71922

Spencer, Dale C. 2012. Ultimate Fighting and Embodiment. New York: Routledge.

Wacquant, Loïc. 2011. "Habitus as Topic and Tool: Reflections on Becoming a Prizefighter." Qualitative Research in Psychology 8(1): 81-92. https://doi.org/10.1080/14780887.2010.544176

2004. Body and Soul: Notebooks of an Apprentice Boxer. New York: Oxford University Press.

\section{[24:20]}

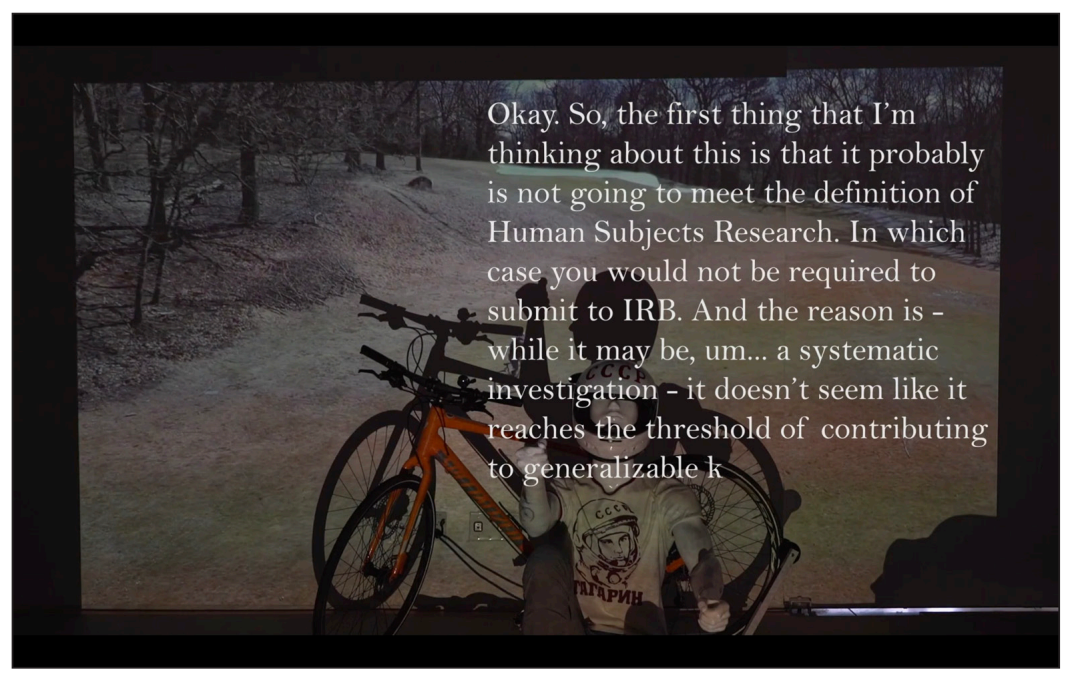

Meeting the Definition of Human Subjects Research: A Case Study

\section{Alen Agaronov}

Harvard T.H. Chan School of Public Health 
Federal guidelines demand that research involving human beings, also known as Human Subjects Research, be reviewed by an ethics committee to ensure it upholds ethical standards. Guidelines broadly define research as any systematic investigation designed to develop or contribute to generalizable knowledge. The extent to which a single human subject can achieve generalizability thus determines whether such practices as self-experimentation qualify as Human Subjects Research, and hence, whether they demand ethics oversight. This study uses found footage of video projected over animate and inanimate objects to explore how this bureaucratic debate over generalizability, sample size, research and ethics is embodied by investigators performing self-experimentation. In the video, an investigator is seen struggling to dress their body double for a visual installation while standing in front of a video projector playing video diary entries on a loop. The light cast from the video projector imbues their bodies with life and casts shadows on a wall immediately behind them. Both bodies are further superimposed by text transcript from a phone conversation between the investigator and an IRB (Institutional Review Board) officer.

So... tell me about your project...

Well, I don't really know how often IRB office deals with this type of research -

Well, give me some details about what it is you are planning and what the process would be.

Sure. Essentially, this will be a study of myself. I will be studying my experience over a period of time. It would involve no one else. Basically, I will be recording a video, like, every day, like a short one. Maybe a minute long? For like a year. I will also code the videos, or data - label them and move around and such - before publishing my findings in, like, a very reputable scientific journal... Um, yeah...

... Okay. So, the first thing that I'm thinking about this is that it probably is not going to meet the definition of Human Subjects Research. In which case you would not be required to submit to IRB. And the reason is - while it may be, um... a systematic investigation - it doesn't seem like it reaches the threshold of contributing to generalizable knowledge. It's really more of a case study sort of thing...

What if I want IRB, to lend legitimacy to the science? I can make the case study very systematic. Does that make sense?

$\cdots$

Well, the IRB has to work with federal regulations, so it would still not fall under Human Subjects. I mean, we can say we reviewed it, and we can say it sort of meets basic ethical standards, but not much more than that. Finding the right journal for publishing is a better way to infer its legitimacy.

[27:22]

Hello! How's it going?

Hello. Hello.

How are you doing?

Has anyone else been in here today, other than you guys?

Oh wow.

Yeah, I'm sure they're coming.

What?

I'm sure they're coming, right?

Yeah. In the afternoon.

...I don't think so...

[More conversation in the background, inaudible]

...A space heater and a laptop...

... What is the generalizable knowledge to which you're hoping to contribute? I don't think it's just your experience.
Journal of Embodied

Research

DOI: $10.16995 /$ jer.91 
It seems like you need an $\mathrm{N}$ of - well, more than you.

Bigger $\mathrm{N}$, as in, more participants?

Yes, rather than just yourself. Studying your experience - I'm not sure if that transfers to generalizable knowledge. It's more of a case study, which can get published and I think case studies are important and can definitely contribute to... um... what.... people... know... Yeah.

Can you make an exception to the federal guidelines? Or, what can I do to make it qualify for Human Subject Research?

Ensure generalizability, or universality of a widely applicable knowledge. It must contribute to knowledge. Yes it needs to be systematic, but the sticking point here is the generalizable piece.

How can I make it more generalizable?

I'm just so used to people trying to sneak out of IRB, that - Look, you can submit to IRB but I suspect you will get a determination that is most in line with federal regulations. We have to apply them and that's just how they define it - Non-Humans Subjects. It's not at all a judgment on your project.

What if I signed my own consent form.

It wouldn't make sense. That's like a rubber stamp, like, "Sure, go ahead." You have control over your own data. Autonomy is key, as in, "Are you doing this with your own free will?" Now, confidentiality is a risk, yes, but that's if data breach the research context. Whereas you - you just risk disclosing your data within the context of your own, uh, life... And if you choose not to sign a consent form for your own study, then why do it in the first place?

What if, by the time I read the consent, I decide not to do it? Maybe it sounds like a good idea now, but when the time comes, I won't want to do it anymore?

Ask yourself, "What universal question am I trying to answer?" With just you, it's hard to say it's generalizable and not just a case study. It would certainly be important knowledge to put out there, and publish, don't get me wrong, but not in a generalizable context.

My suggestion is to have it determined as Not Human Subjects Research. Then, submit to a journal and when they say, "Where is the IRB approval?" you will say "It was reviewed by the IRB. Look, here is the determination."

They get a determination from us. But they don't necessarily care what the determination says as much as you have a determination at all. You know?

\section{COMPETING INTERESTS}

The authors have no competing interests to declare.

\section{AUTHOR AFFILIATIONS}

Angela Viora (D) orcid.org/0000-0003-4718-5367

Monash University, AU

Al Evangelista (D) orcid.org/0000-0003-1729-8870

Oberlin College and Conservatory, US

Sonia York-Pryce (D) orcid.org/0000-0003-2518-2851

Griffith University, AU

Claire Vionnet (D) orcid.org/0000-0002-8763-5070

Anthropologist \& Dancer, Bern, $\mathrm{CH}$

\section{André Dramé}

Former Dancer, Cie Jant-Bi, Dakar, SN

W. Donnie Scally (D) orcid.org/0000-0001-5357-8322

Independent Scholar

Alen Agaronov (D) orcid.org/0000-0002-8441-8089

Harvard T.H. Chan School of Public Health, US 


\section{REFERENCES}

Barad, K. 2007. Meeting the Universe Halfway: Quantum Physics and the Entanglement of Matter and Meaning. Durham, NC: Duke University Press. DOI: https://doi.org/10.2307/j.ctv12101zq

Bowman, P. (ed.) 2018. The Martial Arts Studies Reader. London: Rowman and Littlefield International.

Daughtry, MJ. 2015. Listening to War: Sound, Music, Trauma and Survival in Wartime Iraq. New York: Oxford University Press. DOI: https://doi.org/10.1093/acprof:oso/9780199361496.001.0001

De Beauvoir, S. 1977. Old Age. Translated by Patrick O’Brian. Harmondsworth: Penguin Books.

de Grave, J-M. 2011. The Training of Perception in Javanese Martial Arts. In Martial Arts as Embodied Knowledge: Asian Traditions in a Transnational World. Farrer, DS and Whalen-Bridge, J (eds.), 123143. Albany: State University of New York Press.

Downey, G. 2007. Producing Pain: Techniques and Technologies in No-Holds-Barred Fighting. Social Studies of Science, 37(2): 201-226. DOI: https://doi.org/10.1177/0306312706072174

Downey, G. 2014. 'Habitus in Extremis': From Embodied Culture to Bio-Cultural Development. Body and Society, 20(2): 201-226. DOI: https://doi.org/10.1177/1357034X14524603

Eidsheim, NS. 2015. Sensing Sound: Singing and Listening as Vibrational Practice. Durham, NC: Duke University Press. DOI: https://doi.org/10.2307/j.ctv1220mg3

Espiritu, YL. 2014. Critical Refuge(e) Studies. In: Body Counts: The Vietnam War and Militarized Refugees. University of California Press. pp. 1-23.

Gullette, MM. 2003. Acting Age on Stage: Age Appropriate Casting, the Default Body and Valuing a Property of Having an Age. Journal of Dramatic Theory and Criticism, 18(1): 7-28.

Haargenrud, H. Use my Body While It Is Still Young, Hege Haargenrud (NO) Coda Dance Festival, Norway, VIMEO, https://vimeo.com/2997489492015.

Habito, CF. 2021. 'Mano po' and other treasures. https://opinion.inquirer.net/109755/mano-po-treasures.

Hahn, T. 2007. Sensational Knowledge: Embodying Culture through Japanese Dance. Middletown, CT: Wesleyan University Press.

Hahn, T. 2006. 'It's the RUTH': Sites of the Sensually Extreme. The Drama Review, 50(2): 87-96. DOI: https://doi.org/10.1162/dram.2006.50.2.87

Haraway, D. 1991. Simians, Cyborgs, and Women: The Reinvention of Nature. New York: Routledge.

Haraway, D. 2016. Staying with the Trouble: Making Kin in the Chthulucene. Durham, NC: Duke University Press. DOI: https://doi.org/10.2307/j.ctv11cw25q

Jackson, ZI. 2020. Becoming Human: Matter and Meaning in an Antiblack World. New York: New York University Press. DOI: https://doi.org/10.18574/nyu/9781479890040.001.0001

Jaquet, D and Deluz, V. 2018. Moving in Late Medieval Harness: Exploration of a Lost Embodied Knowledge. Journal of Embodied Research, 1(1): 2 (20:49). DOI: https://doi.org/10.16995/jer.7

Kosnik, AD. 2017. Perfect Covers: Filipino Musical Mimicry and Transmedia Performance. Verge: Studies in Global Asias, 3(1). DOI: https://doi.org/10.5749/vergstudglobasia.3.1.0137

Kozel, S. 2007. Closer: Performance. Technologies. Phenomenology. Cambridge, MA: MIT Press. DOI: https://doi.org/10.7551/mitpress/9780262113106.001.0001

Lilja, E. 2006. Movement as the Memory of the Body: New Choreographic Work for the Stage. Translated by Frank Perry. Stockholm: University of Dance, Committee for Artistic Research and Development.

Morris, G. 2001. Bourdieu, the Body, and Graham's Post War Dance. Dance Research: The Journal of the Society for Dance Research, 19(2 Winter): 52-82. http://www.jstor.org/stable/1290976. DOI: https:// doi.org/10.3366/1290976

Mroz, D. 2020. Taolu - The Master of Space. Martial Arts Studies, 10: 9-22. DOI: https://doi.org/10.18573/ mas. 111

Nakajima, N. 2017. "Overview” In The Aging Body in Dance: A Cross Cultural Perspective, edited by Nanako Nakajima and Gabriele Brandstetter, 11-27. London and New York: Routledge. DOI: https://doi. org/10.4324/9781315515335

Rancière, J. 2009. The Emancipated Spectator. Translated by Gregory Elliot. London, New York: Verso.

Redmond, S. 2020. Everything Man: The Form and Function of Paul Robeson. Durham, NC: Duke University Press. eBook. DOI: https://doi.org/10.1353/book.71922

Spencer, DC. 2012. Ultimate Fighting and Embodiment. New York: Routledge. DOI: https://doi. org/10.4324/9780203142912

Tully, R. 2008. On the Teaching of Classical Ballet, A Manual. Rome: New Books.

Wacquant, L. 2004. Body and Soul: Notebooks of an Apprentice Boxer. New York: Oxford University Press.

Wacquant, L. 2011. Habitus as Topic and Tool: Reflections on Becoming a Prizefighter. Qualitative Research in Psychology, 8(1): 81-92. DOI: https://doi.org/10.1080/14780887.2010.544176

York-Pryce, S. 2020. A body of work. Journal of Dance, Movement \& Spiritualities, 6(1 \& 2): 133-153. DOI: https://doi.org/10.1386/dmas_00007_1

York-Pryce, S. “Ageism and the Mature Dancer”. Thesis. Griffith University. DOI: https://doi.org/10.25904/ 1912/3928
Viora et al.

Journal of Embodied

Research

DOI: 10.16995/jer.91 
Journal of Embodied

Research

DOI: $10.16995 /$ jer.91

TO CITE THIS ARTICLE: Viora, A, Evangelista, A, York-Pryce, S, Vionnet, C, Dramé, A, Scally, WD and Agaronov, A. 2021. Six Illuminated Videos. Journal of Embodied Research, 4(2): 2 (31:25). DOI: https://doi. org/10.16995/jer.91

Submitted: 24 July 2021

Accepted: 24 July 2021

Published: 11 October 2021

COPYRIGHT:

(c) 2021 The Author(s). This is an open-access article distributed under the terms of the Attribution-NonCommercialNoDerivatives 4.0 International License (CC BY-NC-ND 4.0), which permits unrestricted use, distribution, and reproduction in any medium, provided the original author and source are credited. See https:// creativecommons.org/licenses/ by-nc-nd/4.0/.

Journal of Embodied Research is a peer-reviewed open access journal published by Open Library of Humanities. 